\title{
Molecular Cloning and Characterization of Chick CD9
}

\author{
TERUKAZU KOBAYASHI \\ Division of Cell Biology, Institute of Life Science, Kurume University, \\ Kurume 839-0861, Japan
}

\begin{abstract}
Summary: CD9 is a tetra-membrane-spanning glycoprotein involved in cell adhesion, migration, growth signaling and tumor cell metastasis. In this study a CD9 cDNA clone has been isolated from chick CDNA library. The chick CD9 clone contains an open reading frame of 224 amino acids. The deduced amino acid sequence from chick CD9 shows $63.3 \%$ identity with the human counterpart. Human and monkey CD9 upregulate the diphtheria toxin (DT) binding activity of human heparinbinding EGF-like growth factor, while chick CD9 lacks the ability to upregulate the DT binding activity. Comparison of the amino acid sequence of chick CD9 with that of human CD9 gives a clue to understanding the upregulation mechanism.
\end{abstract}

Key words HB-EGF, diphtheria toxin, CD9, DNA sequence, tetra-membrane-spanning glycoprotein, TM4SF

\section{INTRODUCTION}

CD9, a tetra-membrane-spanning glycoprotein of 24$27 \mathrm{kDa}$, was initially reported to be expressed in preB cells and platelets $[1,2]$ but further studies have revealed that it is expressed in a wide variety of hematopoietic and nonhematopoietic cells [3-6]. Increasing evidence suggests that this protein is involved in cell signaling [7,8], cell growth [9], cell motility [10,11], cell adhesion [12-14], tumor cell metastasis [15-17] and development and maintenance of the neural system [18-21].

One characteristic feature of CD9 is the high potential of this protein to form complexes with other membrane proteins [11,22-24]. Earlier studies demonstrated that $\mathrm{CD} 9$, originally reported as DRAP27 [5], associates with diphtheria toxin receptor (DTR) and that DRAP27/CD9 upregulates the diphtheria toxin (DT) binding activity of DTR $[6,22]$. DTR is also known to be the membraneanchored form of heparin-binding EGF-like growth factor (proHB-EGF) [25]. Not only the DT binding activity, but also the juxtacrine mitogenic activity of proHB-EGF is upregulated by CD9 [9]. CD9 also forms complexes with integrin $\alpha 3 \beta 1$ [23], $\alpha 6 \beta 1$ $[24,26]$ and the neural adhesion molecule L1 [11]. In monkey Vero cells, complexes comprising CD9, proHB-EGF and integrin $\alpha 3 \beta 1$ localize at cell-cell adhesion sites, suggesting the involvement of those complexes in intercellular signaling.

CD9 belongs to a member of the tetra-membrane-spanning protein superfamily (TM4SF), which includes CD37, CD53, CD63, CD81 and CD82 [27]. This family of proteins is characterized by four transmembrane domains and conserved cysteine residues at the putative extracellular domain. Although the general function of this family has not been shown, this family of proteins has been described in a wide variety of animal cells including C. elegans and Drosophila [27]. Because of this family's members tendencies to form complexes with a variety of membrane proteins, they are thus thought to be 'adapters for membrane proteins,' or 'molecular facilitators,' that mediate the formation of large molecular complexes and allow them to function more efficiently $[27,28]$.

This paper describes molecular cloning of CD9 cDNA from a chick embryo spinal cord cDNA library and compare the amino acid sequence with its mammalian counterparts. This report is the first description of a vertebrate CD9 other than from mammals. Using the isolated chick CD9 cDNA, the

Received for publication February 9, 2000

Address correspondence to: Terukazu Kobayashi, Division of Cell Biology, Institute of Life Science, Kurume University, 2432-3 Aikawa, Kurume 839-0861, Japan. Tel: 81-942-37-6317 Fax: 81-942-31-3320 
upregulation activity of chick CD9 for the DT binding of proHB-EGF was examined.

\section{MATERIALS AND METHODS}

\section{Cloning of chick CD9 cDNA}

Fragments encoding the open reading frame of mouse CD9 cDNA was labeled with ${ }^{32} \mathrm{P}$ and used to screen a chick CD9 lambda ZAP embryonal spinal cord cDNA library (Clonetec). Hybridization was carried out under the following conditions: prehybridization at $60{ }^{\circ} \mathrm{C}$ for $2 \mathrm{hrs}$ in church buffer $(7 \%$ SDS, $560 \mu \mathrm{M} \mathrm{Na}_{4} \mathrm{P}_{2} \mathrm{O}_{7}, 85.5 \mathrm{mM} \mathrm{Na}_{2} \mathrm{HPO}_{4}, 40 \mathrm{mM}$ $\mathrm{NaH}_{2} \mathrm{PO}_{4}, 2$ mM EDTA) followed by hybridization under the same conditions for $16 \mathrm{hrs}$ in the presence of the ${ }^{32} \mathrm{P}$-labeled probe. The filters were washed three times with $2 \times$ sodium citrate (SSC) containing $0.1 \%$ SDS at $55{ }^{\circ} \mathrm{C}$ for $15 \mathrm{~min}$. Positive clones were isolated, subcloned into pBluescript II $\mathrm{SK}(-)$. Nucleotide sequences were determined by the dideoxy chain termination method using DNA Sequencing Kit with AmpliTaq DNA Polymerase (Perkin Elmer) and a DNA Sequencing System, Model 373S (Perkin Elmer).

\section{Plasmid constructions}

Plasmids encoding monkey CD9 (pRcT1843) were used as described previously [6]. pRc/Flag was constructed from pRc/CMV (Invitrogen Corp): The synthetic oligonucleotides encoding Flag sequence (5'-AAAAAATCTAGAGACTACAAGGACGACGATGACAAGTGAAGGGCCCTTTTTT-3,' and 5'AAAAAAGGGCCCTTCACTTGTCATCGTCGTCCTTGTAGTCTCTAGATTTTTT-3') were annealed, digested with $X b a I$ and $A p a I$ and then inserted into $X b a I / A p a I$ sites of $\mathrm{pRc} / \mathrm{CMV}$. To express Flag-tagged monkey CD9 protein, the cDNA encoding monkey CD9 (pRcT1843) was amplified by polymerase chain reaction with 5'-GTAATACGACTCACTATAGGGC-3' and 5'-AAAAAATCTAGAATAGACCATCTCGCGGT-3' as primers. The amplified fragments were digested with Hind III and $X b a I$ and inserted into the corresponding sites of pRc/Flag. Chick CD9 cDNA was subcloned into $X b a I$ and $A p a I$ sites of $\mathrm{pRc} / \mathrm{CMV}$, and the resulting plasmid named $\mathrm{pRc} / \mathrm{chCD}$ 9. To express Flag-tagged chick CD9 protein, DNA fragments were amplified using pRc/chCD9 as a template with 5'-GTAATACGACTCACTATAGGGC-3' and 5'ATTAATTAGCGGCCGCCGGACCATTTCTCTGTTTCT-3' as primers. The amplified fragments were digested with
Hind III and NotI and inserted into the corresponding sites of $\mathrm{pRc} / \mathrm{Flag}$.

\section{SDS-PAGE and immunoblot}

Cells were lysed by $1 \%$ Triton X-100 in lysis buffer ( $0.15 \mathrm{M} \mathrm{NaCl}, 2 \mathrm{mM}$ EDTA, $1 \mathrm{mM}$ PMSF, 1 $\mathrm{mM} \mathrm{NaVO}$, $50 \mathrm{mM}$ Tris, $\mathrm{pH} 7.5$ ), then lysates were centrifuged for $20 \mathrm{~min}$ at $15,000 \mathrm{~g}$. The supernatants were then boiled for $5 \mathrm{~min}$ in SDS-PAGE sample buffer without reducing agents, subjected to SDSPAGE $(15 \%$ gel) and electrotransferred to an Immobilon membrane. The membrane was blocked with $3 \%$ skim milk at room temperature for $60 \mathrm{~min}$, then incubated at room temperature with the first antibody at a concentration of $2 \mu \mathrm{g} / \mathrm{ml}$ in Tris- $\mathrm{HCl}$ buffered saline (TBS (20 mM Tris-HCl, $100 \mathrm{mM}$ $\mathrm{NaCl}, \mathrm{pH} 7.5)$ ) containing $1 \%$ skim milk and $0.2 \mathrm{M}$ $\mathrm{NaCl}$. After washing with TTBS (TBS containing $0.05 \%$ Tween 20), the membranes were incubated with horseradish peroxidase (HRP)-conjugated antimouse IgG (Chemicon) at a concentration of $2 \mu \mathrm{g} / \mathrm{ml}$, washed with TTBS, and analyzed with an ECLWestern blotting kit (Amersham International).

\section{Cell culture and transfection}

Mouse LH cells, which are a stable transformant of mouse L cells expressing human proHB-EGF, were cultured in Dulbecco's modified Eagle medium (DMEM) supplemented with $10 \%$ fetal calf serum (FCS), $100 \mathrm{U} / \mathrm{ml}$ of penicillin $\mathrm{G}$ and $100 \mu \mathrm{g} / \mathrm{ml}$ of streptomycin. Transfection of plasmids into LH cells was done as described previously [29]. Transfected cells were cultured for $48 \mathrm{hrs}$ and then used for further studies.

\section{DT binding assay}

Purified DT was labeled with $\mathrm{Na}^{125}$ I using enzymobeads as reported previously [30]. The labeled DT had a specific activity of about $1.5 \times 10^{4} \mathrm{cpm} / \mathrm{ng}$. LH cells were plated on 12 -well plates at $5 \times 10^{4}$ cells/well and incubated for $12 \mathrm{hrs}$ at $37{ }^{\circ} \mathrm{C}$. The cells were incubated with ${ }^{125} \mathrm{I}$-labeled DT $(100 \mathrm{ng} / \mathrm{ml})$ for $8 \mathrm{hrs}$ at $4{ }^{\circ} \mathrm{C}$ in the binding medium (MEM containing nonessential amino acids, 5\% FCS and $20 \mathrm{mM} \mathrm{N}-2-$ hydoroxyethlpiperazine-N'-2-ethanesulfonic acid (HEPES), pH 7.2). Then cells were washed three times with PBS (phosphate-buffered saline) containing $1 \%$ FCS, lysed with $0.1 \mathrm{~N}-\mathrm{NaOH}$ and cell-associated radioactivity was measured by a $\gamma$-counter. Nonspecific binding of ${ }^{125} \mathrm{I}$-labeled DT was assessed in the presence of a 100-fold excess of unlabeled DT. Specific binding was determined by subtracting the 
nonspecific binding from the total binding obtained with ${ }^{125}$ I-DT alone. The nonspecific binding was less than $10 \%$ of the total binding.

\section{RESULTS}

\section{Molecular cloning of chick CD9 cDNA}

A fragment of mouse CD9 cDNA was used to screen a cDNA library made from chick embryo spinal cord. By 2 cycle hybridization screening as described in MATERIALS and METHODS, one of the positive clones was isolated. Figure 1 shows the DNA sequence of the cloned cDNA and the pre- dicted amino acid sequence. The chick CD9 cDNA comprises 865 nucleotides containing 20 nucleotides 5 -untranslated region, an open reading frame of 672 nucleotides and 173 nucleotides 3'-untranslated region with a poly adenylation signal TATAAA. The open reading frame encodes a protein of 224 residues in length, and the sequence around the first ATG

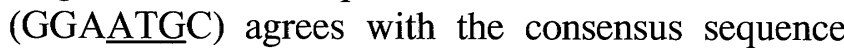
for the initiation of translation. The predicted sequence has four hydrophobic domains which would be deduced as transmembrane domains. One potential N-glycosylation site is located at residue 51 and the conserved CCG motif found in TM4SF proteins at positions 148-150. A comparison of the

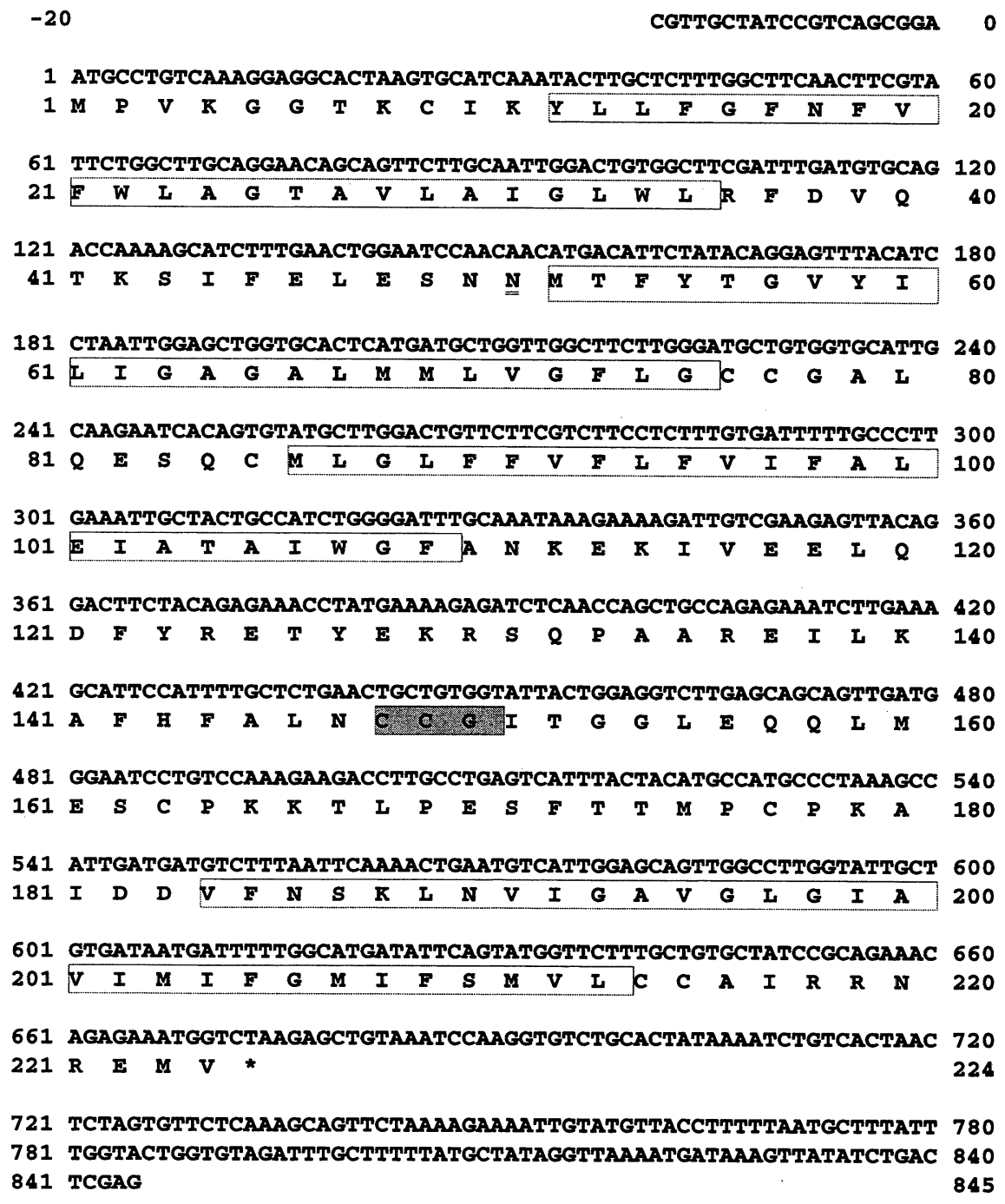

Fig. 1. Nucleotides sequence of chick CD9 cDNA and the predicted amino acid sequence. The putative transmembrane domains and the conserved CCG motif in TM4SF proteins are underlined and box-shaded, respectively. The potential N-glycosylation site is indicated by a double underline. The nucleotide sequence of chick CD9 cDNA has been deposited in the DDBJ, EMBL and GenBank under Accession No. AB032767. 
Chick CD9 Human CD9

Monkey CD9

Mouse CD9

Rat CD9

Feline CD9

Bovine CD9

Chick CD9

Human CD9

Monkey CD9

Mouse CD9

Rat CD9

Feline CD9

Bovine CD9

Chick CD9

Human CD9

Monkey CD9

Mouse CD9

Rat CD9

Feline CD9

Bovine CD9

Chick CD9

Human CD9

Monkey CD9

Mouse CD9

Rat CD9

Feline CD9

Bovine CD9
1 MPVKGGTKCIKYLLFGFNHEWLACTAVLAIGLWLRFAVTKSIFELASNN--MTFYTGY 1 MPVKGGTKCIKYLLFGFNF IFWLAGIAVLAIGLWLRFDSQTKSIFEQETNNNNSSFYTGY 1 MPVKGGTKCIKYLLFGFNFIFWLAGIAVLAIGLWLRFDSQTKSIFEQETLNNNSSFYTGY 1 MPVKGCSKCIKYLLFGFNFIFWLAGIAVLAIGLWLRFDSQTKSIFEQE-- WNHSSFYTGY 1 MPVKGCSKKCIKYLLFGFNFIFWLAGIAVLAIGLWLRFDSQTKSIFEQETD--HSSFYTGY 1 MPVKGGTKCIKYLLFGFNFIFWLAGIAVLAVIGLWLRFDSOTKSIFEdDS--OPSSFYTGY 1 MPVKGGTKCIKYILEGENEIFWLAGIAVISVGLWLREDSOTKSIFEOE-- NADSSEYTGD TM 1

59 YILIGAGALMMLVGFLGCCGALESQCMLGLFAVIFEVIFALEIAIAIWGFANAREIVEA 61 YILIGAGALMMLVGFLGCCGAVQESQCMLGLFFGFLLVIFAIEIAAAIWGYSHKDEVIKA 61 YILIGAGALMMLVGFLGCCGAVQESQCMLGLFFGFLLVIFAIEIAAAIWGYSHKDEVIKA 59 YILIGAGALMMLVGFLGCCGAVQESQCMLGLFFGFLLVIFAIEIAAAVWGYTHKDEVIKA 59 YILIGAGALMMLVGFLGCCGAVQESQCMLGLFFGFLLVIFAIEIAAAUNGITHKDEVIKF

59 YILIGAGALMMLVGFLGCCGAVQIYYXCMLGLFFGFLLVIFAIFIAAAIWGYSHKDEV IDA 59 VILIGAGALMMLVGELGCCGAVOESOCMIGGLESSELLVIEAIN VAAAIWGYSHU EEVIKA TM 2

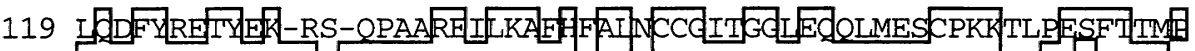

121 VQEFYKDTYNKLXTKDEPQRETLKAIHYAINCCGLAGGVEQFISDICPKKDVLETFTVAS

121 VQEFYKDTYNKI HUKDEPQRETLKAIH YALDCCGLAGGVEQF ISDICPKKDVLEUFIIN

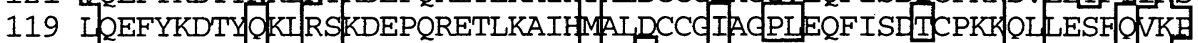

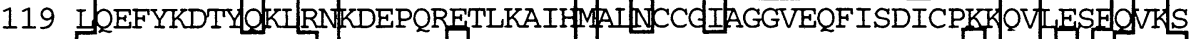

119 VOEFYKDTYNKLA SKDEPQRDILKAIH YALDCCGLAGGVEQFISDIC OA DIL S IIIVKA

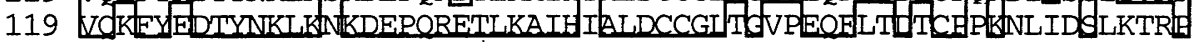

177 CAKAIDDVFNSRNANGAVG GIAZIMIFGMIFSMUCCAIRRNREMY

181 CADAIKEVFDNKFHIIGAVGIGIAVVMIFGMIFSMILCCAIRRNREMY

181 CADAI KEVF DNKFHIIGAVGIGIAVVMIFGMIFSMILCCAIRRNREMY

179 CHEAISEVENUKFHIIGAVGIGIAVVMIFGMIFSMILCCAIRASREMY

179 CHDAIDEVFHSKKFHIIGAVGIGIAVVMIFGMIFSMILCCAIRASREMY

179 CHA A NEVE HNKFHIIGAVGIGIAVVMIFGMIFSMILCCAIRR SREMY

179 CHEA DEIERSKEHI IGAVGIGIAVUMIFGMUESMILCCAIRRNADMV

Fig. 2. Alignment of the amino acid sequences of CD9 proteins from various spices. The conserved amino acids are enclosed in the box. Gaps are indicated as -. An underline indicates the putative transmembrane domains. The most divergent region is the second extracellular domain.

amino acid sequence of the chick CD9 with other mammalian CD9 is shown in Fig. 2. The chick CD9 shows $63.3 \%$ identity with mammalian CD9. As shown in mammalian CD9, the transmembrane domains are highly conserved among chick and mammalian CD9, while the putative second extracellular domain shows relatively large inter-species differences.

\section{Upregulation of the DT binding activity of DTR/proHB-EGF by $C D 9$}

CD9 associates with proHB-EGF/DTR. Human or monkey CD9 upregulates DT binding activity of human proHB-EGF/DTR when CD9 is co-expressed with this protein, though CD9 itself does not have the DT binding property $[9,22]$. Although this upregulation of the DT binding activity by CD9 has been shown to be due to protein-protein interaction, the precise mechanism of upregulation remains to be elucidated. In order to know whether chick CD9 upregulates the DT binding activity of human proHB-EGF/DTR, DT binding assay was performed using cells expressing chick CD9 as follows.

The isolated chick CD9 cDNA clone was subcloned into the eukaryotic expression vector $\mathrm{pRc} / \mathrm{CMV}$, the resulting plasmid is referred to $\mathrm{pRc} / \mathrm{chCD} 9$. For generating CD9 derivatives with known epitope tags, plasmids encoding chick or monkey CD9 with the Flag tag in their C-terminal portions, designated as pRc/chCD9-F and pRcT $1843-\mathrm{F}$, respectively, were also constructed. Mouse LH cells, which are stable transformants of mouse $\mathrm{L}$ cells expressing human DTR/proHB-EGF, were transfected with plasmids encoding chick CD9 (pRc/chCD9), monkey CD9 (pRcT1843) and their Flag-tagged derivatives (pRc/chCD9-F and pRcT 1843-F). The cell lysates were subjected to western blotting analysis (Fig. 3). The anti-human CD9 mAb (TP82) did not cross-react with chick CD9 (data not shown), but anti-Flag antibody showed that Flag- 
Immuno Blot

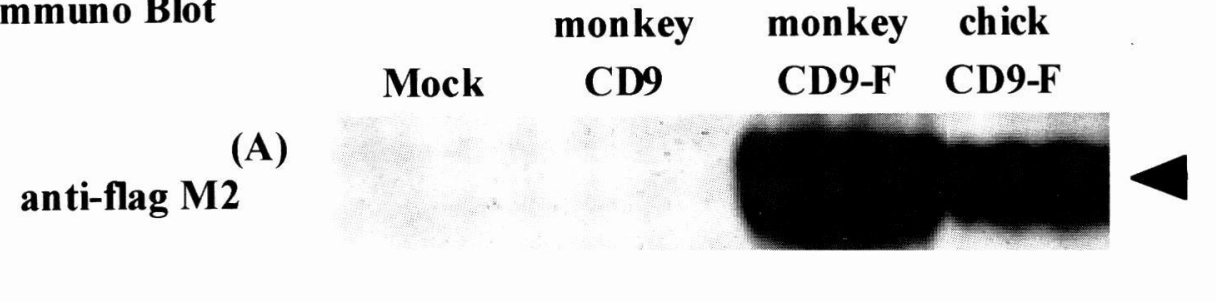

(B)

anti-humanCD9

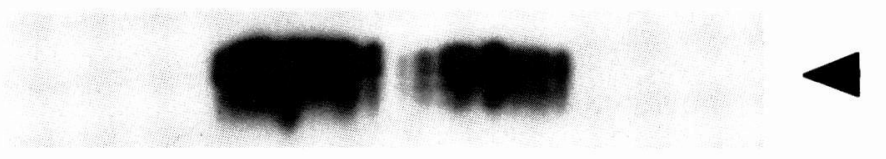

Fig. 3. Western Blotting analysis of chick CD9. LH cells were transfected with cDNA encoding monkey CD9, Flag-tagged monkey CD9 (monkey CD9-F) or Flagtagged chick CD9 (chick CD9-F). Forty-eight hours after transfection cell lysates were analyzed by Western blotting using anti-Flag antibody M2 and anti-human CD9 mAb BU16.

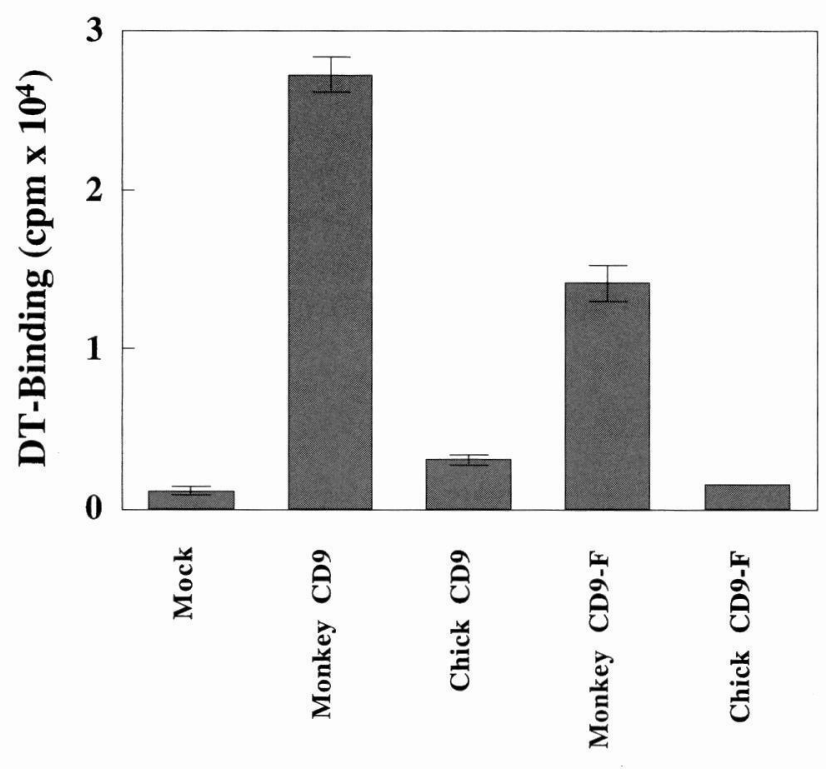

Fig. 4. Effect of CD9 expression on DT binding activity of human proHB-EGF. LH cells were transfected with cDNA encoding monkey CD9, chick CD9 or their Flag-tagged derivatives (monkey CD9-F and chick CD9-F). Forty-eight hours after transfection specific binding of ${ }^{125} \mathrm{I}$-labeled DT to the transfected cells was determined as described in Materials and Methods. Data represent the mean \pm S.D. of the results obtained from triplicate samples. tagged chick CD9 was expressed in LH cells as Flagtagged monkey CD9 was expressed.

Fig. 4 shows the DT binding activity of LH cells transfected with the CD9 constructs. DT binding of LH cells was upregulated 10 fold by the expression of monkey CD9, while it was not upregulated by chick CD9. Flag-tagged monkey CD9 also upregulated the DT binding activity, the same as the native monkey CD9, while Flag-tagged chick CD9 did not upregulate the DT binding activity, though Flagtagged chick CD9 was expressed in LH cells, the same as Flag-tagged monkey CD9. These results indicate that chick CD9 is not competent to upregulate DT binding activity of human DTR/proHBEGF.

\section{DISCUSSION}

Increasing evidence suggests that CD9 and TM4SF proteins are involved in a wide variety of cellular processes during embryonal development and the maintenance of mature individuals [31,32]. In this study chick CD9 cDNA was isolated, and it is the first description of vertebrate CD9 other than in mammals. Because chick is one of the most characterized animals in developmental biology, isolation of a chick counterpart of CD9 would be a useful for the further studies of CD9 functions in development.

The highly conserved amino acid sequence of the 
transmembrane domains of chick CD9, in line with those of other mammalian CD9, implies the importance of those domains in the fundamental role of this protein. Possibly, the regulated formation of complexes of CD9 with various other membrane proteins as a 'molecular facilitator' could be the central role of CD9 and TM4SF proteins [28]. The transmembrane domains might, thus, be important for complex formation.

CD9 is reported to be involved in cell signaling [7,8], cell growth [9], cell motility [10,11], cell adhesion [12-14], tumor cell metastasis [15-17] and development and maintenance of neural system [1821]. However, despite such possibilities of fundamental roles, evidence to demonstrate the function of CD9 at the molecular level is limited. One of the functions of CD9 clearly demonstrated is the upregulation activity of CD9 for proHB-EGF. CD9 greatly upregulates DT binding activity and the juxtacrine mitogenic activity of proHB-EGF $[9,22]$. Although this upregulation of proHB-EGF activities by CD9 is achieved protein-protein interaction, the precise mechanism of upregulation remains to be elucidated. Present studies indicated that chick CD9 is not able to upregulate DT binding activity, probably due to amino acids alterations between chick CD9 and monkey CD9. Further studies will give a clue to understanding the essential regions of CD9 for upregulation, and consequently the upregulation mechanism.

ACKNOWLEDGMENTS: The author greatly appreciates Dr. Eisuke Mekada and members of Division of Cell Biology, Institute of Life Science, Kurume University, for encouragement, suggestion and discussion to promote this work.

\section{REFERENCES}

1. Boucheix C, Soria C, Mirshahi M, Soria J, Perrot JY et al. Characteristics of platelet aggregation induced by the monoclonal antibody ALB6 (acute lymphoblastic leukemia antigen $\mathrm{p} 24$ ). Inhibition of aggregation by ALB6Fab. FEBS Lett 1983; 161:289-295.

2. Kerrsey JH, Lebien TW, Abramson CS, Newman R, Sutherland R et al. P-24: a human leukemia-associated and lymphohemopoietic progenitor cell surface structure identified with monoclonal antibody. J Exp Med 1981; 153:726-731.

3. Boucheix $\mathrm{C}$, Benoit $\mathrm{P}$, Frachet $\mathrm{P}$, Billard $\mathrm{M}$, Worthington RE et al. Molecular cloning of the CD9 antigen. A new family of cell surface proteins. J Biol Chem 1991; 266:117-122.

4. Lanza F, Wolf D, Fox CF, Kieffer N, Seyer JM et al. cDNA cloning and expression of platelet p24/CD9. Evidence for a new family of multiple membrane-span- ning proteins. J Biol Chem 1991; 266:10638-10645.

5. Iwamoto R, Senoh H, Okada Y, Uchida T, and Mekada E. An antibody that inhibits the binding of diphtheria toxin to cells revealed the association of a $27-\mathrm{kDa}$ membrane protein with the diphtheria toxin receptor. J Biol Chem 1991; 266:20463-20469.

6. Mitamura T, Iwamoto R, Umata T, Yomo T, Urabe I et al. The $27-\mathrm{kD}$ diphtheria toxin receptor-associated protein (DRAP27) from vero cells is the monkey homologue of human CD9 antigen: expression of DRAP27 elevates the number of diphtheria toxin receptors on toxinsensitive cells. J Cell Biol 1992; 118:1389-1399.

7. Tai XG, Yashiro Y, Abe R, Toyooka K, Wood CR et al. A role for CD9 molecules in T cell activation. J Exp Med 1996; $184: 753-758$

8. Griffth L, Slupsky J, Seehafer J, Boshkov L, and Shaw ARE. Platelet activation by immobilized monoclonal antibody: evidence for CD9 proximal signal. Blood 1991; 78:1753-1759.

9. Higashiyama S, Iwamoto R, Goishi K, Raab G, Taniguchi $\mathrm{N}$ et al. The membrane protein CD9/DRAP27 potentiates the juxtacrine growth factor activity of the membrane-anchored heparin-binding EGF-like growth factor. J Cell Biol 1995; 128:929-938.

10. Shaw ARE, Domanska A, Mak A, Gilchrist A, Dobler K et al. Ectopic expression of human and feline CD9 in a human B cell line confers beta 1 integrin-dependent motility on fibronectin and laminin substrates and enhanced tyrosine phosphorylation. J Biol Chem 1995; 270:24092-24099.

11. Schmidt C, Kunemund V, Wintergerst ES, Schmitz B, and Schachner M. CD9 of mouse brain is implicated in neurite outgrowth and cell migration in vitro and is associated with the alpha 6/beta 1 integrin and the neural adhesion molecule L1. J Neurosci Res 1996; 43:12-31.

12. Hadjiargyrou M, and Patterson PH. An anti-CD9 monoclonal antibody promotes adhesion and induces proliferation of Schwann cells in vitro. J Neurosci 1995; 15:574-583.

13. Anton ES, Hadjiargyrou M, Patterson PH, and Matthew WD. CD9 plays a role in Schwann cell migration in vitro. J Neurosci 1995; 15:584-595.

14. Masellis-Smith A, and Shaw ARE. CD9-regulated adhesion. Anti-CD9 monoclonal antibody induce pre-B cell adhesion to bone marrow fibroblasts through de novo recognition of fibronectin. J Immunol 1994; 152:2768-2777.

15. Ikeyama $S$, Koyama $M$, Yamako $M$, Sasada $R$, and Miyake M. Suppression of cell motility and metastasis by transfection with human motility-related protein (MRP-1/CD9) DNA. J Exp Med 1993; 177:1231-1237.

16. Miyake $M$, Koyama $M$, Seno $M$, and Ikeyama $S$. Identification of the motility-related protein (MRP-1), recognized by monoclonal antibody M31-15, which inhibits cell motility. J Exp Med 1991; 174:1347-1354.

17. Si Z, and Hersey P. Expression of the neuroglandular antigen and analogues in melanoma. CD9 expression appears inversely related to metastatic potential of melanoma. Int J Cancer 1993; 54:37-43

18. Kaprielian Z, Cho KO, Hadjiargyrou M, and Patterson 
PH. CD9, a major platelet cell surface glycoprotein, is a ROCA antigen and is expressed in the nervous system. $\mathrm{J}$ Neurosci 1995; 15:562-573.

19. Tole S, and Patterson PH. Distribution of CD9 in the developing and mature rat nervous system. Dev Dyn 1993; 197:94-106.

20. Nakamura Y, Iwamoto R, and Mekada E. Expression and distribution of CD9 in myelin of the central and peripheral nervous systems. Am J Pathol 1996; 149:575-583.

21. Kagawa T, Mekada E, Shishido Y, and Ikenaka K. Immune system-related CD9 is expressed in mouse central nervous system myelin at a very late stage of myelination. J Neurosci Res 1997; 50:312-320.

22. Iwamoto R, Higashiyama S, Mitamura T, Taniguchi N, Klagsburn $\mathrm{M}$ et al. Heparin-binding EGF-like growth factor, which acts as the diphtheria toxin receptor, forms a complex with membrane protein DRAP27/CD9, which up-regulates functional receptors and diphtheria toxin sensitivity. EMBO J 1994; 13:2322-2330.

23. Nakamura K, Iwamoto R, and Mekada E. Membraneanchored heparin-binding EGF-like growth factor (HBEGF) and diphtheria toxin receptor-associated protein (DRAP27)/CD9 form a complex with integrin alpha 3 beta 1 at cell-cell contact sites. J Cell Biol 1995; 129:1691-1705.

24. Berditchevski F, Zutter MM, and Hemler ME. Characterization of novel complexes on the cell surface between integrins and proteins with 4 transmembrane domains (TM4 proteins). Mol Biol Cell 1996; 7:193-207. 25. Naglich JG, Metherall JE, Russel DW, and Eidels L. Expression cloning of a diphtheria toxin receptor: identity with a heparin-binding EGF-like growth factor precursor. Cell 1992; 69:1051-1061.

26. Hadjiargyrou M, Kaprielian Z, Kato N, and Patterson $\mathrm{PH}$. The tetraspanin superfamily: molecular facilitators. J Neurochem 1996; 67:2505-2513.

27. Maecker HT, Yodd SC, and Levy S. Association of the tetraspan protein CD9 with integrins on the surface of S16 Schwann cells. FASEB J 1997; 11:428-442.

28. Hemler EM. Integrin associated proteins. Curr Opin Cell Biol 1998; 10:578-585.

29. Chen CA, and Okayama H. Calcium phosphate-mediated gene transfer: a highly efficient transfection system for stably transforming cells with plasmid DNA. Biotechniques 1988; 6:632-638.

30. Umata T, and Mekada E. Diphtheria toxin translocation across endosome membranes. A novel cell permeabilization assay reveals new diphtheria toxin fragments in endocytic vesicles. J Biol Chem 1998; 273:8351-8359.

31. Kopczynski CC, Davis GW, and Goodman CS. A neural tetraspanin, encoded by late bloomer, that facilitates synapse formation. Science 1996; 271:1867-1870.

32. Tachibana I, and Hemler ME. Role of transmembrane 4 superfamily (TM4SF) proteins CD9 and CD81 in muscle cell fusion and myotube maintenance. J Cell Biol 1999; 146:893-904. 